\title{
Knowing people making music. \\ Toward an Epistemology for Fieldwork in Ethnomusicology; or How Do We Know What We Know?
}

\section{Poems}

Fiddling in the horse stalls at Galax

The mingling caws of six crows

circling

a stand of red spruce.

Budget film making

Drop your standards

And I'll shoot.

The fieldworker's stances

Tourist

Lover

Collector

Participant/Observer

Scientist

Detective

Cross-Examiner

Spy

Ole buddy

Visitor

Guest

Host

Thief

Donor

Meddler

Bore

Gone native

Went native.

The post structuralist trots

I've got the world in a text,

The stopper in my right hand. 


\section{Every schoolchild knows}

\section{Musical being in the world}

Worlds of Music --title of ethnomusicology textbook, edited by Jeff Titon. New York: Schirmer Books, 1984.

\section{The fieldworker as sympathetic friend}

"That is not to say the [fieldworker] is passive as a doorknob; he nods assent, interposes a comment, frames a relevant question; indeed, his presence and reactions are essential...He may coincidentally be a folklorist, but his role is mainly that of a sympathetic friend." --Jeff Titon, "The Life Story," Journal of American Folklore, 93 (1980): 276.

\section{Herman Fenoman}

"Hermeneutic phenomonology, then, seems to me to be the best available framework, as today's folklorist contemplates the affective performance of folklore within a community within memory and history. But to my knowledge no folklorist or ethnomusicologist has attempted an interpretive work from this standpoint." --Jeff Titon, "Folklife Studies and Religion," Mid-America Folklore, 13, no. 2 (1985), p. 11.

\section{The limits of reading}

"The task of interpretation involves understanding the significance and meaning of the texts in the context of their performance and in the context of the wider world. Ordinary procedures of literary criticism will not do. Literary critics assume that meaning is revealed to the intelligent reader in an encounter with the written text. Properly trained and familiar with the conventions of the text at hand, the critic derives a sensible interpretation. For written literature this is well and good. But the meaning of language [music] performed orally in a folk group is often so context-bound that attempts to work primarily from the transcribed texts are misguided. In other words, in the church context, with a particular group of worshipers, meaning is personal and even eccentric." --Jeff Titon, Powerhouse for God (Austin: University of Texas Press, 1988), p. 12.

\section{People making music}

"I like to think of ethnomusicology simply as the study of people making music. People 'make' music in two ways: they make or construct the idea of music, what it is (and is not) and what it does; and they make or produce the sounds that they call music." --Jeff Titon, Worlds of Music (2nd ed., New York: Schirmer Books, 1992), xxi. 


\section{Melville on fieldwork}

". . . the great Leviathan is that one creature in the world which must remain unpainted to the last. True, one portrait may hit the mark much nearer than another, but none can hit it with any considerable degree of exactness. So there is no earthly way of finding out precicely what the whale looks like. And the only mode in which you can derive even a tolerable idea of his living contour, is by going awhaling yourself; but by so doing, you run no small risk of being eternally stove and sunk by him. Wherefore, it seems to me you had best not be too fastidious in your curiosity touching this Leviathan." --Herman Melville, Moby-Dick, chapter 55.

\section{Meditations}

\section{Scaffolding}

Invention versus discovery. The thing that is "discovered" was already there, but now it is newly constructed.

\section{The prison-house of music}

Musical knowing follows not from analogies with language or language games but from musical being; that is, from being in the world musically, which means consciousness of music as music.

\section{Three step recovery}

First, attend phenomenologically to my experience of music. Next, to my experience of fieldwork. Then, attend phenomenologically to my experience of making ethnography.

\section{He wuz de man}

De Man as collaborator? My friend Geoffrey Movius told me that to get tenure he would have kissed ass if he could have figured out whose.

\section{Fieldwork and relation}

Not I-it, but I-thou.

\section{The pretext}

All theories of meaning, modern and post-modern, structuralist and post-structuralist, marxist, phenomenological, feminist, semiotic, hermeneutic, have at least one thing in common: they turn the world into texts and tell us how to read them. 
But the musical world does not come to me primarily in texts nor is it easily transformed into texts. Therefore I assert a different epistemology for music, an epistemology of musical being, in the pre-text. And that is my pretext for this alternative epistemology.

\section{This case will suit}

Reading a text is your paradigm case of interpretive being in the world. But making music is my paradigm case. Making music links me to people through being and time, not through action considered as a text; through shared presence mediated by music, not words.

\section{Sequence on making music: 1}

Desire compels me to make music. Making music begins with my experience of sound. Sound overcomes me with longing. The sound grows louder, larger until everything else is shut out including my self-awareness. There is nothing but desiring and sound. Eventually sound returns me through desiring to myself. I am conscious of longing, conscious of sound. I look at myself making music.

\section{Sequence on making music: 2}

Desire compels me to know people making music. Knowing people making music begins with my experience of music. Music overcomes me with longing. The music grows louder, larger until everything else is shut out including my self-awareness. My thinking is shut out. My knowing is shut out. What I knew as music becomes sound. There is nothing but a desiring being, and sound. Eventually sound returns me through desiring to myself. I am conscious that longing is my longing, that sound is music. The "I" returns and I see that we are making the music that I hear.

\section{Sequence on making music: $2 A$}

Desire compels me to know people making music. I feel this desire as an affective presence, a residue of pleasure built up from my previous experiences with music and dance that makes me seek it out in order to know it better. I feel it as an intellectual curiosity but also very much a curiosity of all my bodily senses and I feel it embodied in them: an embodied curiosity. Knowing people making music begins with an experience of music. I hear music; I feel its presence; I am moved, internally; I move, externally. Music overcomes me with longing. I feel its affective power within me. Now I have moved from what phenomenologists call the "natural attitude," the normal everyday way of being in the world, not to the analytical way but to the self-aware way. I feel the music enter me and move me. And now the 
music grows louder, larger until everything else is impossible, shut out. My self disappears. No analysis; no longer any self-awareness. The shutting out is a phenomenological reduction, what Husserl called epoché. It is a radical form of suspension. My thinking is shut out. My knowing is shut out. What I knew as music becomes sound. There is nothing but a desiring being, and sound, noesis and noematic correlate. Sometimes desiring is mixed with fearing. I do not stay in that state forever. Eventually sound returns me through desiring to myself. That is, the be-ing of desiring brings me to myself, re-presents myself to consciousness. Now I am conscious that longing is my longing, that sound is music. The "I" returns; I am self-aware, I see that we are making the music that I hear.

\section{Sequence on making music: 3}

I see that we are making the music that I hear. I want to know you. For us to understand one another we must know one another. How may we know one another? Who are you? If you were an object I might come to know you as I know other objects. If you were an object I would inquire as to your structure, your biochemical makeup, your position and velocity and mass and acceleration; I would want to be able to predict where you are at a given future instant. But you are a person making music and I come to know you as a person. We enter the world of interpretation. Interpretation turns sound into music, be-ing into meaning.

\section{Sequence on making music: 4}

My phenomenology has taken a hermeneutic turn. But I do not always know what I need to know and I do not hear all that the words and all that the music are meaning to me. I am having trouble entering your life-world. I decide I must preserve the words, the music, the gestures. I turn on the camera, the tape recorder, the video camcorder. I make documents, texts out of sounds, words, music, dance. I am discovering texts yet I am also generating texts. And as a scholar I know what to do with texts: interpret them; determine the codes that generate them. I have no time for that at this moment; they come too fast. So I will leave you for awhile and study my texts and to study myself studying my texts. I write this down in my journal.

\section{Musical being and musical knowing}

When my consciousness is filled with music I am in the world musically. My experiencing mind tells me that I have a musical way of being in the world when I make music and when I listen and move to music so that it fills my body and mind. I call this ontology "musical being" and I feel that it is a different kind of being from my normal everyday modes of experiencing and from my self-conscious modes of experiencing and from by objectivizing modes of experiencing. 
I would like to ground musical knowing - that is, knowledge of or about music - in musical being. I look, in other words, for an epistemology of music that is grounded not in a detached or objectivizing, scientific way of being in the world, nor in a reflexive, self-conscious way of being in the world, nor either in what phenomenologists call the "natural attitude" or everyday way of being in the world. Rather, I think that musical being is a special ontology and that knowing music requires that we start from musical being.

Another way of saying this is that I want to ground musical knowledge in the practice of music, not in the practice of science, or linguistics, or introspective analysis. That leads me to inquire further about musical being; my method initially is phenomenological and introspective, but at a later point it draws on other people's testimonies, turns all of these into texts, then circles hermeneutically back and forth between texts and experience, musical knowing and musical being.

\section{History}

\section{Expeditions}

From the first incarnation of ethnomusicology as comparative musicology to the present time, ethnomusicologists have conceived fieldwork as collecting and data gathering. Herndon and McLeod: "Undoubtedly, the most important aspect of ethnomusicology today is the actual gathering of information in the field" (Field Manual for Ethomusicology, [Norwood, PA: Norwood Editions, 1983], p. 1.). That is the first sentence in the only book ever written on the subject of ethnomusicological fieldwork. Home is the archive, the study, the university; the field is "away from home." Ethnomusicological fieldwork is rooted in the heroic quest and in nineteenth-century scientific observation, description, analysis, classification, comparison, and explanation. Fieldwork is the expeditionary part of the process: bring it back alive. Of course, the most accomplished fieldworkers harbored doubts about the procedure. Bartok wondered, for example, whether the specimens brought back on phonograph cylinders from the field were not like those lifeless flower petals pressed between the pages of a book. Today in our library's "new book" section lies the more recent attempt to explain ethnomusicology: Ethnomusicology, An Introduction, edited by Helen Meyers (New York: Norton, 1992). Its first chapter continues to outfit ethnomusicologists for field expeditions. Plus ça change.

\section{The end of comparative musicology}

Comparative musicology, in my view, ends with the cantometrics project of Alan Lomax. Applying scientific criteria, Lomax obtained a sample of the world's music and subjected it to computer analysis in such a way that musical and cultural correlations were tested. He found a connection between elements of song structure 
and of social structure. His most ambitious claim was that the music and culture evolved together from simple to complex, and he traced the musical and cultural paths of migration from one continent to the next and throughout human history in what he termed an "evolutionary taxonomy of culture." ("The Evolutionary Taxonomy of Culture," Science, Vol. 177, July 21, 1972). His scientific results conformed to accepted statistical methods. He received millions of dollars from the federal government to carry out this project. It was complete by 1979. If its goals had been achieved, why didn't the study of world music then cease? Most ethnomusicologists felt that Lomax's data were too thin, and that "elements of song structure" and "elements of social structure" were no longer at the heart of what they wanted to know about music. The quest had turned personal.

\section{Fieldwork and the heroic quest}

Fieldwork inscribes the heroic quest into ethnomusicology. It requires the ethnomusicologist to act out the mythic geography: the discovery of the lack of knowledge at home, the journey to a far country after special training and the acquisition of magical powers such as music literacy, lessons in an exotic language, bimusicality, and the possession of magical instruments such as the camera and tape recorder. The encounter with the monster becomes an encounter with the "Other." The "Other" is not overcome by force but by guile in interviews whose object is to elicit valuable information which, combined with the texts generated from recordings, the fieldworker transports back home. But we may ask of the fieldworker what we would ask of the hero: why is it so hard to come back? Yeats knew the answer: the hero was transformed by experience. The hero now embodied knowledge that transcended the gathered texts. How to impart that knowledge to the kingdom? No wonder fieldworkers find it so hard to write when they return! No wonder fieldworkers tell stories.

\section{Fieldwork and values}

The transformation of the fieldworker as hero is effected not only in identity but in values. A turning point in my construction of the history of ethnomusicology occurred with the work of David McAllester. Shortly after World War II Margaret Mead asked him about a connection between music and cultural values, and she suggested that he pursue that connection among the Navajo. McAllester had spent the previous year, his first as an ethnomusicologist-in-training, doing musical transcriptions under the supervision of George Herzog. Among the Navajo, McAllester became interested in the Peyote music and ceremonies, but he was not allowed to observe unless he participated. How could he? Would his values permit him? Would his participation be authentic? Would it be scientific? $\mathrm{He}$ ate the buttons with the rest and he was transformed. 


\section{Grammatically incorrect}

Is ethnomusicology doomed to borrow ideas after they have outlived their usefulness in other disciplines? Consider the influence of culture grammars, sometimes called ethnoscience. Culture grammars: as proposed by Goodenough and others in the 1950s, a culture was not a list of items or a lexicon of traits or a set of behaviors that could be analyzed and compared. Instead a culture was a set of rules, like unto grammatical rules, that caused behavior. When I studied anthropology in the 1960s this was the model I learned. I incorporated it into my musical analysis of blues in my doctoral dissertation. It was hot stuff then. Ethnoscience has worked itself out in folklore studies in North America since the 1960 s as ethnography of speaking and as performance theory: verbal art as performance. It entered ethnomusicology and is particularly evident in work of Blacking, Herndon, and McLeod from the 1970s.

\section{A wrong turn}

No doubt the most influential thinker upon younger people the field in the 1980s was the anthropologist Clifford Geertz. Drawing upon some of the ideas of Schliermacher and Dilthey, Geertz made what he called "an interpretive turn" in ethnography. More than a turn, it was a paradigm shift. For Geertz, culture was not a list of traits to be described and compared nor a set of rules to be derived, but a group of texts to be interpreted and understood. For Geertz, as for Ricoeur, any meaningful action was a text and subject to "thick description," but certain actions were particularly rich in meaning, and rituals were the richest of all. But how was a text to be interpreted, and by whom? Geertz defended the classic position of the ethnographer as observer, as outsider, contemplating texts but not fully experiencing them. In his work in Bali, how much, I wonder, did he close up the distance between himself and the people he studied, through experience and dialogue? He does not disclose it.

\section{Toward a new epistemology for fieldwork:} knowing people making music

\section{Knowing persons}

Working with music in the field inevitably involves working with people; it is, in George Marcus's words, messy and qualitative, for it is only back in the archive or study that the people depart, leaving their disembodied sounds and words, texts, for analysis and interpretation. When I was editing the Powerhouse for God film, because on the editing screen the people did not vanish but were there, their images insistently embodying their words and music, I could not know music without knowing persons. The images were combined with the sounds to remind me. That 
was eight years ago. I have found feminist epistemology very helpful in forging a new epistemology for knowing music. The objective, scientific model for knowing, i.e., knowing objects, and particularly knowing atomic particles, has come to stand in our society for the truest and best and most important kind of knowledge. There is no need to rehearse the horrific social consequences that have followed from our adopting this objectifying model. Like the feminists, I question the model and favor a different one, a model based on knowing persons, not objects. Objects are known through manipulation, experimentation, dominance. Persons are known through experience, dialogue, and empathy. To know people I turn to narrative, I think and write in stories. This is what an epistemology of fieldwork based on musical being leads me to. But I cannot stay in the field forever. I cycle between field and home, experiencing music and experiencing texts, writing narrative and interpreting texts. Ethnomusicology is more than fieldwork, but its epistemological ground emanates from the experience of sound which people make into music.

\section{Etymology}

FIELDwork. A field is a piece of land given over to pasture or tillage, usually fenced in. Originally its sense was of a piece of open ground as opposed to woodland or forest. The Indo-European root is pele from which are derived such words as plenitude, plenty, plain, and explain [out of the field]. To ex-plain is to bring in from the field, a nice etymology for me as a bean and apple grower engaged in explanation and understanding. These are, also, nurturing metaphors; farm metaphors; and I prefer them to the military metaphors (a legacy of class struggle?) that bristle throughout the field of cultural studies.

An epistemology for ethnomusicology begins with fieldwork, with knowing people making music. This knowing is experiential and participatory; it is based on a musical way of being in the world which is, I believe, a special kind of being and knowing, special in the sense that it differs from the kind of being and knowing that typifies scholarship and is represented by the ethnomusicologist, alone, in the library, or the study, contemplating a text, and thinking and writing about it. The differences between these ways of being and knowing produce a tension and a dialectic which leads, ideally, to a way of knowing that incorporates musical experience into the texts we, as scholars, generate. 